\title{
Perhekustannusten tasauksen aste Suomessa
}

\author{
Valtiot. maist. ANTERO PERÄLÄINEN \\ Väestöliitto
}

Lapsilisien, verohelpotusten ja muiden perhekustannusten tasaukseen vaikuttavien tekijöiden merkityksestä lapsiperheiden taloudessa ei meidän maassamme ole suoritettu yksityiskohtaisia tutkimuksia ja sen vuoksi näistä asioista julkisuudessa keskusteltaessa esitetäänkin usein liioittelevia tai muuten harhaanjohtavia tietoja. Täsmällisten tietojen saaminen onkin vaikeata, koska tasauksen vaikutus riippuu monista tekijöistä: perheen kokonaistulojen määrästä, lasten luvusta ja iästä, rahatulojen ja luontoisetujen suhteesta, äidin ansiotyöstä ym. Perhekustannusten tasaukseen vaikuttavat eräissä tapauksissa myös sellaiset seikat kuin asunto- ja koulutusavustukset. Kaikkia mahdollisia tekijöitä ei kuitenkaan voida ottaa huomioon asiaa yleisesti tarkasteltaessa, koska tutkimuksen suorittaminen muodostuisi kovin monitahoiseksi ja yleiskuvan saaminen vaikeaksi.

Edellisessä vuosikirjassa julkaistussa kirjoituksessa »Lapsilisäjärjestelmät eri maissa» esitettiin eräitä havaintoja lasten perheelle aiheuttamista kustannuksista ja lapsilisien osuudesta tavallisen palkansaajan kuukausiansioista. Nyt on tarkoitus selvittää yksityiskohtaisemmin perhekustannusten tasauksen astetta Ranskassa ja Ruotsissa esitettyjen laskentamenetelmien mukaan ja siinä yhteydessä lasten kulutuksen osuutta perheen kokonaiskulutuksesta. Näiden laskelmien tarkoituksena on siis antaa vastaus kysymykseen, mikä on eri perhetyyppien - lapsiperheiden ja lapsettomien parien - nykyinen kulutustaso. Tällöin lähdetään siitä olettamuksesta, että jos kahdella erisuuruisella perheellä on käytettävissään yhtä suuri summa kulutusyksikköä kohti, niiden katsotaan olevan samalla kulutustasolla. Yleis- kuvan saamiseksi otetaan perheen käytettävissä olevia tuloja laskettaessa huomioon lapsi- ja perhelisät sekä verohuojennukset, mutta ei asunto- eikä opintoavustuksia.

\section{U.I.O.F:n elintasokomission laskenta- menetelmä}

Ensin tutkitaan asiaa perhejärjestöjen kansainvälisen liiton (U.I.O.F.) elintasokomission noudattaman laskuperusteen mukaan ja verrataan tiettyyn palkkaluokkaan kuuluvien erisuuruisten lapsiperheiden kulutustasoa saman palkkaluokan lapsettoman parin tasoon. Laskelmien pohjaksi on mainittu elintasokomissio suorittamissaan kansainvälisissä vertailuissa ottanut palkkaluokan, joka vastaa metalliteollisuudessa työskentelevien ammattitaidottomien miesten keskipalkkaa. Perhetyypeiksi on valittu $1-6$ lapsen perheet sekä vertailun pohjaksi lapseton aviopari. Perheen asuinpaikka on kaupungissa; perheenäidillä ei ole ansiotuloja.

Ensin lasketaan, kuinka suuri summa vuodessa jää perheen käytettäväksi eri perhetyypeissä, kun vuosipalkasta on vähennetty verot ja siihen on lisätty lapsilisät. Sitten arvioidaan, kuinka paljon erisuuruisilla lapsiperheillä pitäisi olla käytettävissään vuoden aikana, jotta niillä olisi kulutusyksikköä kohti sama summa kuin vertauksen pohjaksi otetulla lapsettomalla parilla. Lopuksi verrataan kussakin perhetyypissä käytettävissä olevia tuloja tavoitteeksi asetettuihin summiin ja lasketaan, kuinka monta prosenttia käytettävissä olevat tulot ovat tarvittavista tuloista. Lapsettoman parin käytettävissä oleva tulo otetaan vertailun pohjaksi ja 
Ta ulu 1. Kulutusyksikköä kohti käytettävissä ollut tulo erisuuruisissa perheissä v. 1957.

\begin{tabular}{|c|c|c|c|c|c|c|c|c|c|c|}
\hline 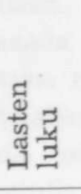 & 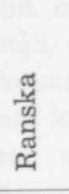 & $\frac{. \frac{\pi}{00}}{\tilde{D}}$ & 恚 & 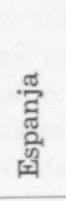 & 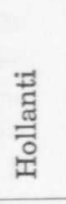 & 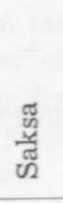 & $\begin{array}{l}\text { घี } \\
\text { जิ } \\
\text { जी }\end{array}$ & $\stackrel{\frac{\pi}{6}}{\stackrel{0}{\circ}}$ & 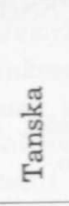 & 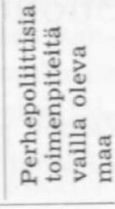 \\
\hline 0 & 100 & 100 & 100 & 100 & 100 & 100 & 100 & 100 & 100 & 100 \\
\hline 1 & 83 & 84 & 88 & 81 & 84 & 84 & 85 & 81 & 81 & 78 \\
\hline 2 & 87 & 76 & 80 & 71 & 73 & 71 & 74 & 70 & 68 & 64 \\
\hline 3 & 91 & 73 & 74 & 64 & 66 & 65 & 66 & 62 & 60 & 54 \\
\hline 4 & 91 & 70 & 70 & 60 & 61 & 61 & 60 & 57 & 54 & 47 \\
\hline 5 & 91 & 70 & 67 & 60 & 57 & 57 & 55 & 52 & 49 & 41 \\
\hline 6 & 91 & 70 & 65 & 60 & 54 & 54 & 51 & 49 & 46 & 37 \\
\hline
\end{tabular}

sen tarpeentyydytysasteena katsotaan olevan $100 \%$. Lapsiperheillä on luonnollisesti käytössään edellä arvioitua tarvetta pienempi summa ja niiden »tyydytysastetta» ilmaiseva prosenttiluku jää alle sadan. Tällä tavoin voidaan asettamalla lapsettoman parin taso vertailun pohjaksi saada selville erisuuruisten lapsiperheiden kulutustaso ja verrata niitä keskenään.

Kun tämän laskutavan mukaan arvioidaan, kuinka suuri summa eri suuruisilla lapsiperheillä pitäisi olla käytettävissään, jotta niiden elintaso olisi sama kuin lapsettoman parin, on arvion pohjana käytetty seuraavia kulutusyksikköjä: lapseton pari on 1,75 ja lapsi 0,5. Yleensä kulutusyksikkölaskelmissa aikuisen miehen kulutusyksikköluku on 1 , naisen 0,9 ja lapsen keskimäärin 0-16 ikävuoden aikana noin 0,6. Kun avioparin kulutusyksikköluku on tässä laskelmassa otettu hieman pienemmäksi kuin yksinäisen miehen ja naisen ky-lukujen summa, on tällöin tavallaan otettu huomioon se, että yhteistaloudessa kulutus on hieman pienempi kuin taloutta erikseen pidettäessä. Lapsen kulutusyksikköluku on myöskin otettu hieman pienemmäksi kuin mitä kulutustutkimuksissa yleensä on käytetty.

Tämäntapaiset laskelmat ovat luonnol-

T a u l u 2. Perhekustannusten tasaukseen vaikuttavat tekijät sekä käytettävissä olevien tulojen määrät eri suuruisissa perheissä ja kolmessa eri tuloluokassa v. 1961 Helsingissä.

\begin{tabular}{|c|c|c|c|c|c|}
\hline & \multicolumn{5}{|c|}{ Vuositulo $450000 \mathrm{mk}$} \\
\hline & \multicolumn{5}{|c|}{ Lasten lukumäärä perheessä } \\
\hline Lapsilisät & 16800 & 33600 & 50400 & 67200 & 84000 \\
\hline $\begin{array}{l}\text { Perhelisät } \ldots \ldots \ldots \ldots \ldots \ldots \ldots \ldots \ldots \ldots \\
\text { Veronalennusten vaikutus yht. } \ldots \ldots \ldots \ldots \ldots\end{array}$ & - & - & - & 5500 & 11000 \\
\hline Veronalennusten vaikutus yht. $\ldots \ldots \ldots \ldots \ldots$ & 10880 & 16880 & 22880 & 28880 & 34880 \\
\hline $\begin{aligned} \text { siitä: veroluokkaetu } & \ldots \ldots \ldots \ldots \ldots \ldots \ldots \ldots \\
& \text { lapsivähennys kunnallisverotuksessa }\end{aligned}$ & $\begin{array}{l}4880 \\
6000\end{array}$ & $\begin{array}{r}4880 \\
12000\end{array}$ & $\begin{array}{r}4880 \\
18000\end{array}$ & $\begin{array}{r}4880 \\
24000\end{array}$ & $\begin{array}{r}4880 \\
30000\end{array}$ \\
\hline $\begin{array}{l}\text { lapsivähennys kunnallisverotuksessa } \\
\text { lapsivähennys valtion tuloverotuksessa } \\
\text { kalliinpaikanvähennys valtionverotuk- }\end{array}$ & - & - & - & - & - \\
\hline $\begin{array}{r}\text { sessa lapsesta } \ldots \ldots \ldots \ldots \ldots \ldots \ldots \ldots \ldots \\
\text { Perhekustannusten tasaukseen vaikuttavat }\end{array}$ & - & - & - & - & - \\
\hline $\begin{array}{l}\text { tekijät yhteensä .............................. } \\
\text { Lapsettoman avioparin käytettâva }\end{array}$ & 27680 & 50480 & 73280 & 101580 & 129880 \\
\hline $\begin{array}{l}\text { vuositulo } \ldots \ldots \ldots \ldots \ldots \ldots \ldots \ldots \ldots \ldots \ldots \ldots \ldots \ldots \\
\text { Lapsiperheen käytettävissä oleva vuositulo }\end{array}$ & $\begin{array}{l}377620 \\
405300\end{array}$ & $\begin{array}{l}377620 \\
428100\end{array}$ & $\begin{array}{l}377620 \\
450900\end{array}$ & $\begin{array}{l}377620 \\
479200\end{array}$ & $\begin{array}{l}377620 \\
507500\end{array}$ \\
\hline & & & & & \\
\hline
\end{tabular}


lisesti aivan karkeita mittaustapoja ja ne esittävät hyvin pelkistetyssä muodossa tilanteen esimerkiksi valituissa tyyppiperheissä. Perhekustannusten tasaukseen vaikuttavista seikoista voidaan näin ollen ottaa huomioon vain tärkeimmät tekijät. Tulokset osoittavat kuitenkin, että lapsiperheiden kulutustaso riippuu aivan ratkaisevasti siitä, kuinka paljon perheellä on käytettävissään tuloja perheenjäsentä tai kulutusyksikköä kohti, ja että eroavuudet erisuuruisten palkannauttijaperheiden kesken ovat suuremmat kuin mitä yleensä ollaan valmiit myöntämään. Näissä laskelmissa ei sensijaan ole otettu huomioon perheenäidin kotiustyön arvoa, ei siis myöskään lasten hoidon vaatimaa työtä eikä siihen käytettyä aikaa. (Kotius-sanaa käytetään kodin taloustieteessä kotitaloussanan asemasta ja kotiustyö merkitsee perheen omaa kulutusta varten kotona suoritettavaa työtä.) Kulutusyksikkölaskelmiin nojautuvassa laskutavassa otetaan siis lapsen kulutuksena huomioon vain hänen henkilökohtaiset menonsa (ravinto, vaatetus, yms.) ja lapsen osuus perheen yhteisistä menoista (asunto, kalusto, yms.), mutta ei äidin palveluksia.

Oheisessa taulussa 1 on esitetty Perhejärjestöjen liiton elintasokomission suorittaman kansainvälisen vertailun tulokset. Suomen osalta tiedot perustuvat vuosiin 1955-56.

Seuraavissa tauluissa on laskettu samojen periaatteiden mukaan nykyinen perhekustannusten tasauksen aste Suomessa metallimiehen perheessä. Sen lisäksi on katsottu, miten tasauksen aste muuttuu tulojen muuttuessa ja kuinka suuri osa lasten kulutuksesta johtuvasta elintason alenemisesta on katettu lasten luvun lisääntyessä ja toisaalta erisuuruisissa perheissä. Lopuksi on laskettu, mitä eräät muutokset perhekustannuksen tasaukseen vaikuttavissa tekijöissä tulisivat merkitsemään.

Esimerkiksi otetun metallimiehen vuosipalkka on 650000 markkaa vuodessa eli noin $54170 \mathrm{mk} / \mathrm{kk}$. Valtion tuloveron määrä on laskettu vuoden 1961 alussa voimaan astuneen veroasteikon mukaisesti ja työtulovähennys $(20 \%)$ on otettu huomioon. Kalliinpaikan vähennykset on tehty sen mukaan kuin ne olivat vuonna 1961 Helsingissä. Kunnan ja kirkon verot sekä kansaneläkemaksu on otettu yhteensä 15 prosentiksi. Lapsivähennys on kunnallisverossa $40000 \mathrm{mk}$ tulosta ja valtionverotuksessa $5000 \mathrm{mk}$ verosta jokaisen lapsen osalta. Lapsilisä on otettu huomioon kaikissa perheissä ja perhelisä niissä perheissä, joiden tulot jäävät alle vahvistetun rajan. Oheisessa taulussa 2 on laskettu, miten eri suuruisten lapsiperheiden käytettävissä oleva tulo muodostuu sekä mitkä tekijät vaikuttavat perhekustannuksia tasaavasti.

Taulu 3 osoittaa perhekustannusten tasauksen asteen metallimiesten perheissä vuonna 1961.

\begin{tabular}{|c|c|c|c|c|c|c|c|c|c|}
\hline \multicolumn{5}{|c|}{ Vuositulo $650000 \mathrm{mk}$} & \multicolumn{5}{|c|}{ Vuositulo $850000 \mathrm{mk}$} \\
\hline \multicolumn{5}{|c|}{ Lasten lukumäärä perheessä } & \multicolumn{5}{|c|}{ Lasten lukumäärä perheessä } \\
\hline 1 & 2 & 3 & 4 & 5 & 1 & 2 & 3 & 4 & 5 \\
\hline 16800 & 33600 & 50400 & 67200 & 84000 & 16800 & 33600 & 50400 & 67200 & 84000 \\
\hline & - & - & & 11 & - & - & - & - & \\
\hline 20980 & 33380 & 41180 & 47180 & 53180 & 26520 & 39200 & 51880 & 64360 & 75360 \\
\hline 8580 & & 8580 & 8580 & & 13840 & 13840 & 13840 & 13840 & 13840 \\
\hline 6000 & 1200 & 18000 & 24000 & 300 & 6000 & 120 & 18000 & & \\
\hline 5000 & 10000 & 10400 & 10400 & 10400 & 5000 & 10000 & 15000 & 20000 & 23600 \\
\hline 1400 & 2800 & 4200 & 4200 & 4200 & 1680 & 3360 & 5040 & 6520 & 792 \\
\hline 37780 & 66980 & 91580 & 119880 & 148180 & 43320 & 72800 & 102280 & 131560 & 170360 \\
\hline 529320 & 29320 & 529320 & 529320 & 5293 & 677140 & 677140 & 677140 & 677140 & 677140 \\
\hline & 596300 & 620900 & 649200 & 677500 & 720460 & 749940 & 779420 & 808700 & 847500 \\
\hline
\end{tabular}


$\mathrm{T}$ a u l u 3. Tasauksen aste metallimiesten perheissä.

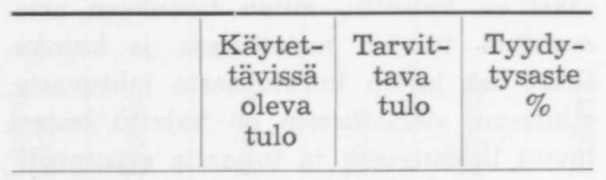

\begin{tabular}{|c|c|c|c|}
\hline $\begin{array}{l}\text { Lapseton } \\
\text { aviopari }\end{array}$ & i . . 530000 & 530000 & 100 \\
\hline \multicolumn{4}{|c|}{ Aviopari, jolla } \\
\hline 1 lapsi & ... 567000 & 680000 & 83 \\
\hline 2 lasta & ... 596000 & 830000 & 72 \\
\hline 3 lasta & .... 621000 & 980000 & 63 \\
\hline 4 lasta & .... 649000 & 1130000 & 57 \\
\hline 5 lasta & ... 678000 & 1280000 & 53 \\
\hline 6 lasta & ... 706000 & 1430000 & 49 \\
\hline
\end{tabular}

Laskelma osoittaa, että kun lasten lukı on 5-6, perheen elintaso on vain puolet vastaavan suuruisia tuloja saavan lapsettoman avioparin elintasosta. Kun lapsettomalla parilla on käytettävissään $n$. 300000 markkaa kulutusyksikköä kohti, on vastaava luku kahden lapsen perheessä 250000 , neljän lapsen 170000 ja kuuden lapsen vain 145000 (kuvio 1).
Jos tavoitteeksi asetetaan, että nuoren parin elintason tulisi pysyä ennallaan lasten luvun lisääntyessä, jokaisen lapsen syntyessä perheen käytettävissä olevien tulojen tulisi lisääntyä 150000 markalla vuodessa eli 12500 markalla kuukaudessa. Tämä luku saattaa ensinäkemältä tuntua korkealta, mutta lähempi tarkastelu osoittaa, ettei se ole liian suuri. Helsingin kaupunki suorittaa yksityiskotiin sijoitetuista lapsista korvauksena ruoasta, vaatteista ja asunnosta keskimäärin 8000 markkaa hoitomaksuna kuukausittain ja huoltaja saa sen lisäksi lapsilisän.

Erittäin tuntuva menoerä, jonka suuruutta ei yleensä huomata, on lapsen vaatima tila perheen asunnosta. Jos lapsettoman parin katsotaan asuvan tyydyttävästi silloin, kun sillä on käytettävissään kaksi huonetta ja keittokomero, tulisi kahden lapsen perheellä olla kolmen huoneen ja keittiön asunto eli noin $15-20 \mathrm{~m}^{2}$ suurempi tila. Yhden lapsen vaatima lisätila olisi siis puolet lasten makuuhuoneesta sekä sen lisäksi joitakin neliöitä yhteisestä olohuoneesta ja keittiöstä eli 8-10 $\mathrm{m}^{2}$. Nykyisen arava-vuokratason

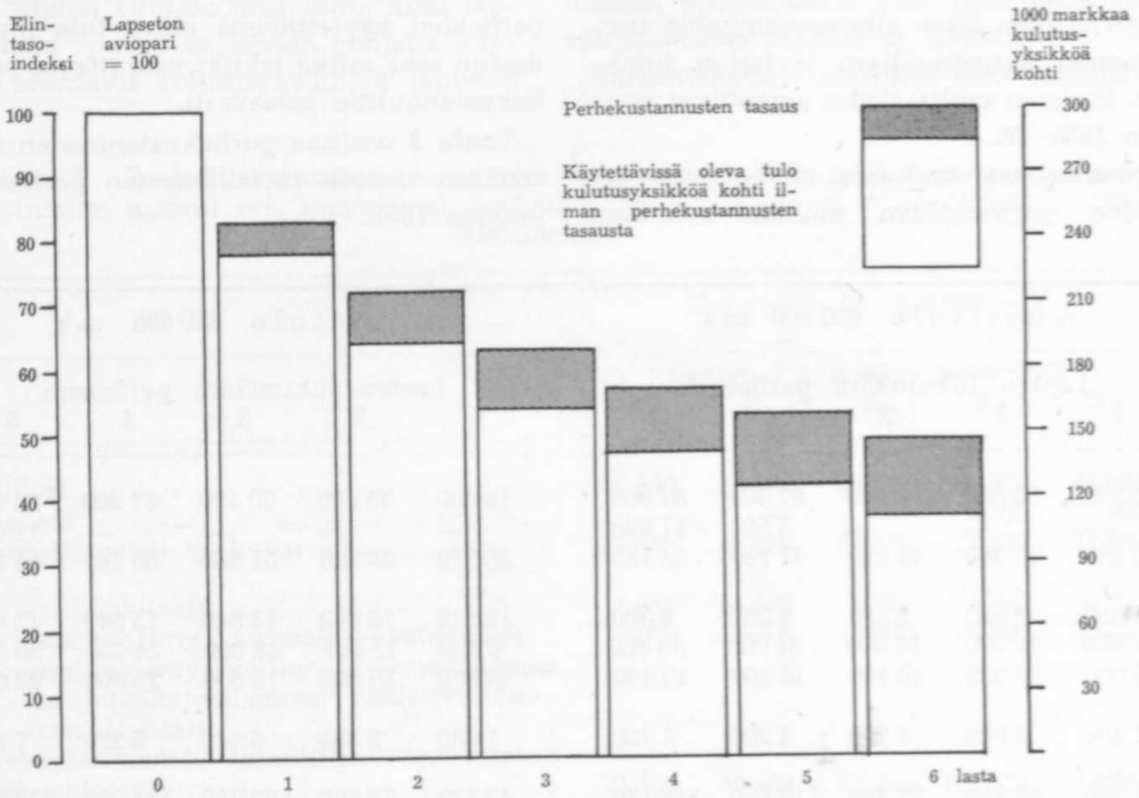

K uvi o 1. Käytettävissä oleva tulo kulutusyksikköä kohti erisuuruisissa perheissä Suomessa v. 1961. 
T a ulu 4. Lapsen kulutus keskimäärin kaikissa 2-lapsisissa perheissä v. 1955 kaupungeissa ja kauppaloissa suoritetun kulutustutkimuksen perusteella.

(E. v. Hofstenin Ruotsin komiteamietinnössä »Samhället och Barnfamiljerna» esittämän jakomenetelmän mukaan.)

\begin{tabular}{|c|c|c|c|c|c|c|}
\hline \multirow{2}{*}{ Menoryhmä } & \multirow[t]{2}{*}{$\begin{array}{c}\text { Koko } \\
\text { kulutus } \\
\mathrm{mk} / \mathrm{v}\end{array}$} & \multirow{2}{*}{$\begin{array}{c}\text { Perheen } \\
\text { yhteinen } \\
\text { kulutus } \\
\mathrm{mk} / \mathrm{v}\end{array}$} & \multirow{2}{*}{$\begin{array}{c}\text { Perheen- } \\
\text { jäsenten } \\
\text { henk.koht. } \\
\text { kulutus } \\
\mathrm{mk} / \mathrm{v}\end{array}$} & \multicolumn{2}{|c|}{$\begin{array}{l}\text { Lapsen kulu- } \\
\text { tuksen osuus }\end{array}$} & \multirow{2}{*}{$\begin{array}{l}\text { Yhden } \\
\text { lapsen } \\
\text { kulutus } \\
\mathrm{mk} / \mathrm{v}\end{array}$} \\
\hline & & & & yht. & henk. & \\
\hline Ravinto & 239280 & - & 239280 & - & $21.75 \%$ & 52043 \\
\hline Asunto & 70800 & 70800 & - & $1 / 6$ & - & 11800 \\
\hline Lämpö ja valo ..... & 29450 & 29450 & - & $1 / 6$ & - & 4908 \\
\hline Kankaat, langat ym. .......... & 11440 & - & 11440 & - & $1 / 4$ & 2860 \\
\hline Valmiit vaatteet ........... & 68530 & - & 68530 & - & $*)$ & 8500 \\
\hline Jalkineet $\ldots \ldots \ldots \ldots \ldots \ldots \ldots$ & 14550 & - & 14550 & - & $*)$ & 2855 \\
\hline Kalusto, vuodev, ja taloustarv. & . 39310 & 39310 & - & $1 / 4$ & - & 9827 \\
\hline $\begin{array}{l}\text { Henkilökoht. puhtaus, pesu ja } \\
\text { siiv }\end{array}$ & 23090 & 6820 & 16270 & $1 / 4$ & $1 / 6$ & 4417 \\
\hline 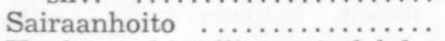 & 14420 & - & 14420 & - & $1 / 4$ & 3605 \\
\hline Koulutus, kirjallisuus ja lehdet & 17400 & 8700 & 8700 & $1 / 6$ & $1 / 6$ & 2900 \\
\hline Posti ja puhelin..$\ldots \ldots \ldots \ldots$. & 2420 & 2420 & - & $1 / 6$ & - & 403 \\
\hline Huvit ja urheilu $. . . \ldots \ldots \ldots . .$. & 19450 & 9725 & 9725 & $1 / 4$ & $1 / 6$ & 4052 \\
\hline Matkat ja lomat ....... & 32527 & 21714 & 10856 & $1 / 10$ & $1 / 6$ & 3980 \\
\hline Vakuutus- ja yhd.maksut .... & 4730 & 2365 & 2365 & $1 / 20$ & $1 / 20$ & 236 \\
\hline Alkoholi, tupakka, lahjat .... & 32810 & - & 32810 & - & - & - \\
\hline Kotiapulainen yms. .......... & 9390 & 9390 & & $1 / 4$ & - & 2348 \\
\hline \multirow{2}{*}{ Muut menot $\ldots \ldots \ldots \ldots \ldots \ldots$} & 14360 & 2872 & 11488 & $1 / 4$ & $1 / 6$ & 2632 \\
\hline & 644000 & - & - & & & 117366 \\
\hline
\end{tabular}

*) Lapsen kulutusmenot saatu suoraan kulutustutkimuksesta.

mukaan se merkitsisi noin 3000 markan menoerää kuukaudessa. Käytännössä tähän ei kuitenkaan päästä tässä tuloluokassa, vaan perheen on tyydyttävä tuntuvasti pienempään asuntoon - usein kaksioon. Kulutustutkimukset osoittavatkin, että lapsiperheet joutuvat asuntomenojen ohella tinkimään myös sellaisista menoista, jotka eivät ole ehdottoman tarpeellisia, kuten matkat, harrastukset, kulttuurimenot, nautintoaineet, ja että ravinnon laatukin on usein heikompi lapsiperheissä kuin lapsettomissa.

\section{Lapsen kulutuksen osuus perheen kulutuksessa}

On mielenkiintoista todeta, että lapsen kulutuksen osuus kaksilapsisen perheen kokonaiskulutuksesta on Ruotsissa suoritettujen, kulutustutkimuksiin perustuneiden arvioiden mukaan aivan sama kuin elintasokomission suositteleman laskuta- van mukaan. Yhden lapsen kulutuksen osuus on kummassakin tapauksessa 17$18 \%$ perheen koko kulutuksesta eli noin kuudesosa, kun äidin kotiustyötä ei oteta huomioon. Ruotsissa on Erland v. Hofsten suorittanut yksityiskohtaisia laskelmia vuoden 1952 kulutustutkimuksen aineiston perusteella. Hän on tarkastellut tilannetta perheissä, joissa on isä, äiti ja kaksi lasta. Koko kulutus on ensin jaettu toisaalta perheen yhteiseen kulutukseen ja toisaalta perheenjäsenten henkilökohtaiseen kulutukseen. Lapsen osuus kummastakin ryhmästä on sitten arvioitu eräiden menoerien osalta kulutusyksikköperiaatteen mukaan, jolloin yhden lapsen osuus on $1 / 6$, tai »pääluvun» mukaan, jolloin lapsen osuus on $1 / 4$ yhteisestä tai henkilökohtaisesta kulutuksesta. Eräissä tapauksissa lapsen osuus on arvioitu vielä pienemmäksi ja joidenkin menoerien osalta on kulutustutkimuksesta suoraan saatu selville lapsien aiheuttamat menot, 
T a u lu 5. Tasauksen aste kolmessa tuloluokassa.

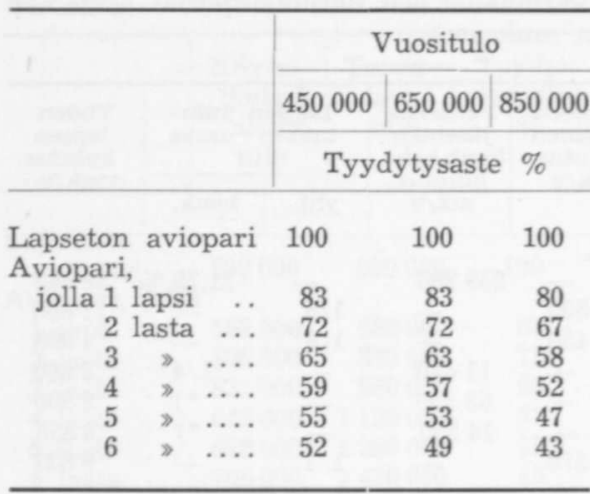

kuten esim. lasten vaatetusmenot. Meidän olojamme ajatellen $v$. Hofstenin selvitykset antavat jopa selvemmän kuvan lapsen kulutuksen rakenteesta ja määrästä kuin elintasokomission suosittelema kaava. Laskelmat on julkaistu v. 1955 ilmestyneessä komiteamietinnössä »Samhället och barnfamiljerna». Siinä todetaan, että v. 1955 kahden lapsen perheissä yhden lapsen henkilökohtainen kulutus oli keskimäärin 120, osuus yhteisestä kulutuksesta sen lisäksi 45 ja äidin kotiustyö arviolta 125 kruunua kuukaudessa.

Oheisessa taulussa 4 on laskettu tämän menetelmän mukaan meillä v. 1955 suoritetun kaupunkien kulutustutkimuksen aineiston perusteella yhden lapsen kulutuksen rakenne ja määrä. Tämän mukaan lapsen kulutus olisi silloin ollut täällä vajaa 10000 markkaa kuukaudessa. Sen jälkeen on elinkustannusindeksi noussut noin $40 \%$.

Kun vuosina 1959-60 suoritetun maaseudun kulutustutkimuksen aineistosta palkansaajaperheiden osalta lasketaan samalla tavoin yhden lapsen kulutuksen määrä, todetaan sen olevan $107500 \mathrm{mk}$ vuodessa eli noin $9000 \mathrm{mk}$ kuukaudessa. Kahden lapsen perheiden kulutus, verot poisluettuina, oli tällöin keskimäärin $555000 \mathrm{mk}$ vuodessa.

\section{Tasauksen aste eri tuloluokissa}

Oheinen taulu 5 osoittaa, miten perhekustannusten tasauksen aste vaihtelee tulojen muuttuessa. Metallimiehen 650000 markan vuositulon lisäksi on otettu 450000 markan vuositulo, joka edustanee asutuskeskusten sekatyöläisen vuosipalkkaa, ja 850000 markan vuositulo, joka vastaa nuoremman lehtorin peruspalkkaa (n. valtion $26 \mathrm{pl}$.).

Vertailu osoittaa, että perheen tulojen kasvaessa tasauksen vaikutus hieman heikkenee. Näin on asianlaita, vaikka valtionverotuksessa pienituloiset lapsiperheet eivät saa lapsivähennystä kaikista lapsista ja vaikka toisaalta toisen ja kolmannen veroluokan välinen erotus, veroluokkaetu, tulojen kasvaessa suurenee. Taulusta 2 käy ilmi, että sekatyömiehen perhe ei maksa lainkaan valtionveroa, metallimies vapautuu tuloverosta, kun hänellä on kolme tai useampia lapsia, ja lehtori viidennestä lapsesta alkaen. Samoin nähdään, että jos sekatyömiehellä on kolme lasta, lapsi- ja perhelisät ovat yhtä suuret kuin maksetut verot. Hänellä on siis silloin palkkatulo vähentymättömänä käytettävissään. Metallimies on samassa asemassa, kun hänellä on neljä lasta, ja lehtori, kun lapsia on viisi. Jos muutkin verotuksessa myönnettävät vähennykset kuin lapsivähennykset otetaan lukuun, käytettävissä oleva tulo muodostuu hieman suuremmaksi kuin taulun 2 osoittama.

Tästä laskelmasta voidaan vetää se johtopäätös, että ylempiin tuloluokkiin kuuluvien lapsiperheiden kohdalla tasauksen aste on selvästi pienempi kuin alempiin kuuluvien. Perhekustannusten tasausta

$\mathrm{T}$ a u l u 6. Kulutustason alenemisen kattaminen lapsen järjestysluvun mukaan.

\begin{tabular}{|c|c|c|c|}
\hline $\begin{array}{l}\text { Lapsen } \\
\text { järjestysluku }\end{array}$ & 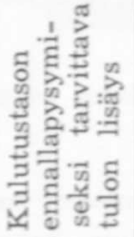 & 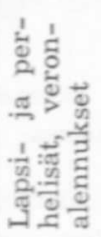 & 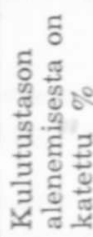 \\
\hline
\end{tabular}

Ensimmäineh ‥ $\quad 150000 \quad 37800 \quad 25$ toinen ....... $150000 \quad 29200 \quad 19$ kolmas ........ $150000 \quad 24600 \quad 16$ neljäs ja seuraava $150000 \quad 28300 \quad 19$ 
kehitettäessä olisi kuitenkin ensisijassa pidettävä päämääränä lasten aiheuttamien vähimmäismenojen korvaamista pienituloiselle perheen huoltajalle nykyistä runsaammin. Perheen tulojen kasvaessa lasten huoltaminen on helpompaa, mutta laskelma osoittaa, että lapsiperheen kulutustaso on kuitenkin aina alhaisempi kuin samaan tuloluokkaan kuuluvan lapsettoman parin.

\section{Tasauksen aste erisuuruisissa perheissä}

Oheisessa taulussa 6 on laskettu, kuinka suuri osa ensimmäisen, toisen, kolmannen jne. lapsen aiheuttamasta kulutustason alenemisesta on nyt katettu perhekustannuksen tasauksen-avulla. Jos tavoitteena pidetään metallimiehen perheessä 150000 markan tulon lisäystä vuodessa jokaisen lapsen osalta, laskelma osoittaa, kuinka paljon perheen käytettävissä olevat tulot kasvavat ja kuinka monta prosenttia tasaustoimenpiteet muodostavat asetetusta tavoitteesta.

Laskelma osoittaa, että ensimmäisen lapsen aiheuttamasta kulutustason painumasta on katettu neljäsosa, kolmannen n. kuudesosa ja neljännen ja sitä seuraavien osalta, kun perhelisä on otettu lukuun, vajaa viidesosa. Se, että prosenttiluku ensimmäisen lapsen osalta on muita korkeampi, johtuu siitä, että yhden lapsen huoltaja saa lukea hyväkseen kokonaisuudessaan toisen ja kolmannen veroluokan välisen veronalennuksen, ns. veroluokkaedun.

Vaikka siis neljännen ja sitä seuraavien lasten aiheuttamasta kulutustason painumasta onkin nykyisin katettu hieman suurempi osa kuin kolmannen ja suunnilleen sama kuin toisen, ovat lapsirikkaat perheet kuitenkin kaikkein heikoimmassa asemassa, kuten alussa esitetty kulutustasovertailukin osoitti. Samaa osoittaa myöskin taulu 7, jossa tarkastellaan, kuinka suuri osa lasten aiheuttamasta kulutustason alenemisesta on katettu eri suuruisissa perheissä.

Ensimmäisestä lapsesta johtuva, muita suurempi veronalennus heijastuu tässä laskelmassa myöskin useamman lapsen
$\mathrm{Ta} \mathrm{ulu}$ 7. Kulutustason alenemisen kattaminen eri suuruisissa perheissä.

\begin{tabular}{|c|c|c|c|}
\hline $\begin{array}{l}\text { Lasten } \\
\text { lukumäärä }\end{array}$ & 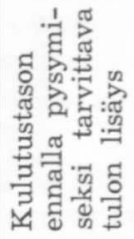 & 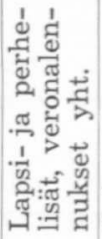 & 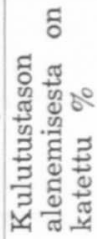 \\
\hline
\end{tabular}

\begin{tabular}{|c|c|c|c|c|c|}
\hline Yhden 1 & & rhe & 150000 & 37800 & \\
\hline kahden & $\gg$ & $\$$ & 300000 & 67000 & \\
\hline kolmen & 》 & $»$ & 450000 & 91600 & \\
\hline neljän & $》$ & $\gg$ & 600000 & 119900 & \\
\hline viiden & $\gg$ & 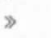 & 750000 & 148200 & \\
\hline kuuden & 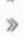 & $\gg$ & 900000 & 176500 & \\
\hline
\end{tabular}

perheisiin, mutta siitä huolimatta tasauksen aste on kolmen ja useamman lapsen perheissä heikompi kuin pienemmissä perheissä.

\section{Lapsilisän porrastamisen vaikutus}

Jos perhekustannusten tasausta haluttaisiin tehostaa siten, että keskitason palkannauttijaperheissä, joita esimerkiksi otettu metallimies edustaa, katettaisiin lasten aiheuttamasta kulutustason painumasta aina yhtä suuri osuus kuin nyt yhden lapsen perheessä eli $25 \%$, tulisi toisesta lapsesta myönnettävää tukea lisätä 8000 markalla, kolmannesta 12900 markalla sekä neljännestä ja sitä seuraavista 9200 markalla vuodessa. Jos tavoitteeksi otettaisiin kolmen ja useamman lapsen perheiden tukeminen niin, että ne tulisivat samalle tasolle, missä kahden lapsen perheet nyt ovat, ja heidän kulutustasonsa alenemisesta katettaisiin $22 \%$, pitäisi kolmen lapsen perheen käytettävissä olevia tuloja lisätä 7400 markalla ja suurempien perheiden 4-5000 markalla vuodessa lasta kohti.

Lapsiperheen käytettävissä olevien tulojen lisääminen voidaan luontevimmin təhdä porrastamalla lapsilisän määrä toisesta ja kolmannesta lapsesta alkaen. Jos meneteltäisiin siten kuin Pekka Kuusi on kirjassaan "60-luvun sosiaalipolitiikka єsittänyt ja korotettaisiin lapsilisä toisesta 
T a u l u 8. Lapsilisän porrastamisen vaikutus eri suuruisissa perheissä.

\begin{tabular}{|c|c|c|}
\hline & 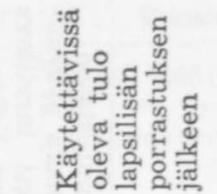 & 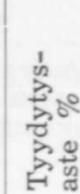 \\
\hline
\end{tabular}

Lapseton aviopari

530000

100

Aviopari, jolla

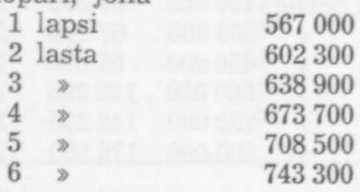

83

73

65

60

55

52

lapsesta 1900 markkaan sekä kolmannesta ja sitä seuraavista alkaen 2400 markkaan, ja luovuttaisiin perhelisistä, katettaisiin lasten aiheuttamasta kulutustason painumasta ensimmäisen lapsen osalta $25 \%$ ja seuraavien aina $24 \%$. Käytettävissä olevien tulojen määrät edellämainitussa metallimiehen perheessä olisivat oheisen taulun 8 mukaiset. Tasauksen astetta osoittavista suhdeluvuista huomataan, kun niitä verrataan tauluun 3 , että lapsirikkaiden perheiden kulutustaso todella nousisi enemmän kuin pienten perheiden.

60-luvun lopulla esitetään mainitussa kirjassa lapsilisiä korotettavaksi toisen kerran ja silloin kalleimmilla paikkakunnilla enemmän kuin halvimmilla.

\section{Veronalennusten vaikutus}

Edellä on taulussa 2 osoitettu, että veronalennukset muodostavat huomattavan osan perhekustannusten tasaukseen vaikuttavista tekijöistä. Ellei verotuksessa otettaisi huomioon huoltovelvollisuutta veronmaksukykyä alentavana tekijänä, tasauksen aste olisi nykyistä heikompi. Kun verotuksen piiriin tulevien perheiden lukumäärä jatkuvasti kasvaa yleisen ansiotason noustessa ja palkansaajien määrän lisääntyessä, on perhekustannusten tasauksen kannalta tärkeätä selvittää, miltä perheiden verotus näyttää perhekustannusten tasauksen kannalta.

Selvyyden vuoksi mainittakoon, että lapsiperheille annettujen verohelpotusten varsinaisena tarkoituksena ei ole tasata perhekustannuksia, vaan niiden avulla pyritään siihen, että lapsiperheiden ei tarvitsisi maksaa veroa kaikista niistä tuloista, joita ne käyttävät lasten elatukseen.

Mainitusta taulusta käy myöskin selvästi ilmi, että ensimmäisestä lapsesta myönnetty verohuojennus on suurempi kuin seuraavista lapsista saatava, koska ensimmäinen lapsi tuo mukanaan veroluokkaedun, jonka määrä kasvaa tulojen kasvaessa, mutta seuraavista lapsista annettava verohuojennus on aina samansuuruinen, $5000 \mathrm{mk}$ vuodessa. Ensimmäisestä lapsesta tulee siis sekä suhteellinen että kiinteä vähennys, muista vain kiinteä.

Keväällä 1951 mietintönsä antanut verolakikomitea on lapsiperheiden veronmaksukykyä selvitellessään tarkastellut ongelmaa, kuinka suuri osa perheen tuloista käytetään kunkin perheenjäsenen hyväksi ja todennut, että perheen tulojen kasvaessa myös jokaisen perheenjäsenen hyväkseen saama määrä kasvaa ja että tämä kulutusyksikköverotuksen johtoajatus on siis oikea. Komitea katsoo, että yleisesti hyväksytyn käsityksen mukaan puolisoiden tulot käytetään yhtäläisesti molempien hyväksi, mutta että sensijaan ei ole yleisesti hyväksytty se käsitys, että perheen tuloista olisi aina käytettävä jokin tietty suhteellinen osuus myös kunkin lapsen hyväksi. Mahdolliselta näyttää, että tulojen kasvaessa lasten hyväksi tuleva osuus pienenee, vaikka asiaa ei olekaan voitu tarkoin tutkia. Ensimmäisen lapsen merkityksestä komitea toteaa, että hänestä aiheutuu vanhemmille suuremmat kustannukset kuin seuraavista lapsista, mutta että valtion tuloverotuksessa easimmäisestä lapsesta annettu verohelpotus on liian suuri, jopa moninkertainen verrattuna muiden lasten vaikutukseen. Komitea esittääkin, että lapsivähennykset tehtäisiin verotettavasta tulosta ja että niiden määrä porrastettaisiin seuraavasti: ensimmäisestä 40000 , toisesta 60000 ja 
jokaisesta seuraavasta $80000 \mathrm{mk}$ vuodessa. Tätä kantaansa komitea on perustellut sillä, että kun lapsivähennystä ei jokaisesta lapsesta voida määrätä riittävän suureksi, vanhemmat pystyvät kantamaan tämän epäkohdan yhden ja ehkä kahdenkin, mutta ei enää useamman lapsen osalta. Jos asiaa tarkastellaan yksinomaan lapsiperheiden kannalta, merkitsisi komitean esittämä muutos lapsirikkaiden perheiden verotaakan alenemista.

Aviopuolisoiden verotuksessa komitea esittää siirtymistä ns. tasausmenettelyyn, jolloin puolisoiden verotettava tulo (silloinkin, kun vaimolla ei niitä ole) jaettaisiin kahdella ja vero määrättäisiin kummallekin puolikkaalle erikseen perusasteikon mukaan. Käytännössä tämä muutos tietäisi sitä, että lapsettoman perheen, jossa vaimolla ei ole tuloja, vero alenisi suunnilleen siihen määrään, minkä kahden lapsen perhe nyt maksaa. Toisaalta yksinäisen henkilön ja p.o. lapsettoman parin maksamien verojen erotus kasvaisi ja, toisaalta lapsettoman parin ja lapsiperheiden suoritettavien veromäärien erotus supistuisi tuntuvasti. Jos asiaa tarkastellaan perhekustannusten tasauksen kannalta, muutos tietäisi tasauksen heikkenemistä. Edellä esitetyt laskelmat perhekustannusten tasauksen asteesta ja lapsiperheiden kulutustasosta lapsettomaan pariin verrattuna muuttuisivat sen johdosta oleellisesti. Uudistuksen tarkoituksena pitäisi pikemminkin olla nykyisen veroluokkaedun jakaminen useamman lapsen huoltajien osalle, kuin sen kertakaikki- nen poistaminen. Sen vuoksi tulosta myönnettävän lapsivähennyksen pitäisi olla suurempi kuin komitean esittämä ensimmäisen ja toisen lapsen osalta myös ainakin $80000 \mathrm{mk}$, ellei haluta supistaa lapsiperheiden nykyisin saamia veroheipotuksia.

Tähän summaan päädytään myöskin, kun katsotaan mikä tulisi olla lapsen verovapaa toimeentulominimi. Kun yksinäisen henkilön tuloista aletaan periä tuloveroa $200000 \mathrm{mk}: \mathrm{sta}$ ja lapsettomalta parilta 400000 markasta alkaen, tulisi lapsiperheen saada vähentää jokaiselta lapselta $100000 \mathrm{mk}$. Kun otetaan huomioon n. 20000 markan suuruinen lapsilisä tulonlisäyksenä, pitäisi verotettavasta tulosta tehtävän lapsivähennyksen olla siis $80000 \mathrm{mk}$.

\section{Kirjallisuus:}

La Dégradation du Niveau de Vie en Fonction des Dimensions de la Famille, U.I.O.F. Familles dans le monde 1953: 3, Paris.

Samhället och barnfamiljerna, SOU 1955: 29, Stockholm 1955.

Pekka Kuusi. 60-luvun sosiaalipolitiikka. Helsinki 1961.

Verolakikomitean mietintö. Komiteamietintö N:o $4-1961$.

Taulukko tulo- ja omaisuusveron määräämistä varten vuodelta 1961 toimitettavassa verotuksessa. Valtiovarainministeriön veroasiainosaston julkaisuja N:o 96 . 